\title{
LETTERS
}

\section{Selection bias}

In a recent research article in CMAJ, ${ }^{1}$ the study population consists entirely of ill travellers self-reporting to a travel clinic upon their return. It seems likely that this would select patients who were either sufficiently unwell or sufficiently worried about their illness to seek medical attention. In light of this, I find it unsurprising that this study ${ }^{1}$ observed a higher incidence of complicated disease than that seen in endemic areas.

Michael S. Jansz MD MSc

Resident, Vancouver Coastal Health, Vancouver, BC

Cite as: CMAJ 2017 May 8;189:E673. doi: 10.1503/cmaj.732958

\section{Reference}

1. Boggild AK, Geduld J, Libman M, et al. Surveillance report of Zika virus among Canadian travellers returning from the Americas. CMAJ 2017;189: E334-40.

Competing interests: None declared. 